\title{
DO TEATRO AO DIGITAL: UMA ONTOLOGIA A PARTIR DE ROMAN INGARDEN
}

\author{
Otávio Guimarães Tavares ${ }^{*}$
}

RESUMO: Este trabalho parte do pressuposto de que é possível, com base nas formulações de Roman Ingarden acerca da ontologia da peça teatral, traçar as bases de uma ontologia da obra de arte digital, tendo em vista convergências entre os modos de operar de ambos os tipos de produções. Estas convergências se encontram: a) no fato de serem obras cuja concretização comporta uma materialidade; b) na complexidade estratificada e na hierarquia ontológica dessas obras capaz de comportar diversos níveis de concretização por distintos agentes humanos e nãohumanos; c) na noção de identidade que é construída perante a multiplicidade de concretizações; e d) no papel da linguagem que se distancia de uma função semântica por um foco acional em que o elemento textual se caracteriza como indicação para um agir performático. Destarte, a partir de tais paralelos, é possível questionar os limites e alcance do conceito de literatura aplicado ao digital (literatura digital ou poesia digital), tendo em vista que a obra de arte digital estaria, por seu modo de operar, mais ontologicamente próxima da peça teatral ou obra de arte dramática. Por fim, torna-se possível tanto revisar a filosofia de Ingarden, de modo a demonstrar sua pertinência como ferramenta teórica para a análise de obras de arte contemporâneas, quanto marcar o lugar central do artefactual e performático nas obras de arte digitais.

PALAVRAS-CHAVE: Literatura Digital. Teatro. Ontologia. Performance. Roman Ingarden.

1 enters at $A$, completes his course and is joined by 3. Together they complete their courses and are joined by 4 . Together all three complete their courses and are joined by 2. Together all four complete their courses. Exit 1. 2, 3 and 4 continue and complete their courses. Exit 3. 2 and 4 continue and complete their courses. Exit 4. End of 1st series. 2 continues, opening 2nd series, completes his course and is joined by 1 . Etc. Unbroken movement.

Samuel Beckett, Quad

\section{Introdução}

Se, nos estudos literários, muitas vezes a obra do filósofo polonês Roman Ingarden é vista como uma análise de certa forma datada ou conservadora, na

\footnotetext{
* Professor no Instituto de Letras e Comunicação da Universidade Federal do Pará, Brasil. E-mail: nonada1@gmail.com 
filosofia o caso tende a ser outro. Além de sua visível influência sobre a ontologia formal, a partir da Controversy over the Existence of the World (2013), ele tem sido lido e referenciado pela filosofia da arte anglófona contemporânea sobretudo em uma análise ontológica da arte -, por autores como Gary Iseminger (1973), Joseph Margolis (1977), Randall Dipert (1986, 1993), Jerrold Levinson (2011) e, especialmente, Amie Thomasson (1999, 2004). Quando não é diretamente referenciado, encontramos formulações teóricas que se aproximam das suas, como é o caso de Arthur Danto (1981, 1986), Graham Mcfee (2011) e Noël Carroll (2003). Margolis (1979) chega a afirmar que Ingarden foi, com sua especificação complexa da configuração ontológica da obra de arte - sua análise acerca do modo de existência da obra de arte -, a maior influência continental europeia sobre os filósofos norte-americanos e britânicos da arte. Talvez porque, como afirma tanto Amie Thomasson (2012) quanto Guido Küng (1994), a maneira pela qual Ingarden trabalha a ontologia ser similar ao tipo de análise conceitual empreendida por filósofos analíticos que trabalhavam por volta do mesma época.

Para entendermos essa influência contemporânea de Ingarden, temos que ter em mente a noção de ontologia da arte atualmente em questão. Poderíamos definir uma investigação desta, a partir de Celso R. Braida (2013), como um estudo e análise de estruturas formais-conceituais das nossas práticas discursivas acerca do artístico. Se a ontologia se pergunta "o que é isso que há", a ontologia da arte se pergunta pelo modo de ser do artístico e o modo de objetivar aquilo que pensamos e falamos acerca dele. Entretanto, não se trata de somente dizer o que há atualmente, mas sim de indicar, a partir de um conceito de arte, o possível, o que pode ser, o que pode existir. A partir da explicitação do que é implícito em nossas práticas de dizeres e pensares acerca do artístico, torna-se possível entender um conceito não como uma delimitação do que há, mas como uma indicação do que pode haver, dos modos possíveis de pensar e compreender esse fazer.

Uma ontologia da arte se perguntaria por: que tipo de coisa são as obras de arte? São elas objetos reais, experiências mentais ou tipos ideais? Se enquadram, todas, na mesma categoria de coisa? São eternas ou podem ser destruídas? 
Dependem de outras coisas para existir ou são autônomas? A partir de quando que uma obra existe? Danos a uma obra de arte fazem com que ela deixe de ser arte? O que define os limites do que é uma obra de arte? O que permite falarmos da "mesma" obra de arte? Duas coisas exatamente iguais são a mesma obra ou obras diferentes? A mesma obra pode ser acessada por pessoas no Brasil e na China? Elas são únicas ou repetíveis? Questionamentos todos implícitos em nossas práticas e dizeres, mesmo quando nos recusamos a conceituar o artístico. No caso presente, me interesso pela análise de Ingarden acerca da ontologia da peça teatral ou da obra de arte literária dramática ${ }^{1}$ e em como esta pode ser utilizada para esclarecer elementos concernentes à obra de arte literária digital de modo a possibilitar o estabelecimento de conceitos base para uma ontologia da obra de arte digital, sobretudo, no que diz respeito à: complexidade e a hierarquia ontológica de uma obra que comporta diversos níveis de concretização por diferentes agentes; a noção de identidade perante a multiplicidade de concretizações; e o papel da linguagem sobre um foco acional, como indicações para um agir performático. Assim, a partir desses dois "casos limite" do literário noção que Ingarden usa para conceituar a peça teatral -, indico o lugar centralidade da ação e da artefactualidade na obra de arte digital.

\section{A peça teatral, a arte digital e o ato performativo}

Se na Literary Work of Art Ingarden (1973) se concentra na concretização intencional de objetividades apresentadas - eventos, cenas, personagens, etc. -, ao longo da obra, ele também trata da atualização ${ }^{2}$ material dos estratos através da declamação (como elocução que concretiza materialmente o dizer) e, de forma mais complexa, o caso da performance a partir da peça teatral, que não só efetiva as potencialidades linguísticas da obra ao modo da declamação, mas também atualiza elementos reais e materiais em coisas e ações físicas ${ }^{3}$.

\footnotetext{
1 Ingarden trabalha com um modelo dramático, enquanto que, atualmente, existem propostas pósdramáticas que trabalham com a ideia de sobreposição, lacuna e de dissociação das diferentes camadas que integram o ato cênico.

2 O termo "atualização" utilizado por Ingarden deve ser entendido como "realização". Aquilo que existe potencialmente, ou em um estado potencial, pode ser realizado, i.e. tornado atual (MITSCHELING, 1999).

${ }^{3}$ Refiro-me, sobretudo, ao $\S 57$ da Literary Work of Art (1973).

Texto Digital, Florianópolis, Santa Catarina, Brasil, v. 12, n. 2, p. 35-58, jul./dez. 2016. ISSNe: 1807-9288.
} 
Neste contexto, o questionamento de Ingarden é quanto à localização e à identidade da obra de arte teatral e que, aqui, serve, da mesma forma, para pensarmos as obras digitais. O que ele percebe é que: 1) há uma pluralidade de execuções, em que cada uma é um acontecimento individual e está fundada em eventos reais; 2) há diferentes detalhes em cada execução; e 3) uma "mesma" peça pode ser mal ou bem executada (INGARDEN, 1973; MITSCHELING, 1999). Temos entre a peça escrita e a peça executada uma similaridade e uma distinção. Ao dizermos que existe a possibilidade de execuções de diferentes qualidades, independentemente da qualidade da peça escrita, damos base, justamente, para estabelecermos a peça escrita e a peça executada como duas entidades distintas. Contudo a pergunta de Ingarden está formulada da seguinte maneira, indicando uma terceira distinção4:

\begin{abstract}
A pergunta é somente se o que está contraposto à execução individual é a obra literária "escrita" ou a "encenação", que é diferente. Se for esta, nós teremos que contrastar obras literárias de um certo tipo (obras "dramáticas") com encenações, que serão vistas como heterogêneas; se for aquela, teremos apenas que aceitar um tipo especial de concretização de obras "dramáticas", a saber, o tipo que é realizado na "execução" (INGARDEN, 1973, p. 318)
\end{abstract}

Ao optar por uma forma da segunda, Ingarden volta sua atenção para o "texto secundário" das didascálias, indicações de atos, movimentações de personagens e outras direções de palco. O texto dramático seria um texto composto para ser executado, materialmente posto em ação ${ }^{6}$. Deste modo, ele é estruturado de uma forma diferente ao de um romance ou poema, no sentido de que ele tem 1) um "texto secundário" que funciona como um texto instrução ou diretriz, abrangendo coisas como: local, quem entre e sai, quem fala, tempo, ações, movimentação no

\footnotetext{
${ }^{4}$ Todas as traduções que seguem são de minha autoria.

5 The question is only whether what is counterposed to the individual performance is the corresponding "written" literary work or a "stage play" that is different from it. If it is the latter, we will have to contrast literary works of a certain kind ("dramatic" works) with stage plays, which will then be seen as heterogeneous to them; if it is the former, we will have to accept only a special kind of concretization of "dramatic" works, namely, the kind that is realized in a "performance" (INGARDEN, 1973, p. 318).

${ }^{6}$ Até mesmo peças teatrais que, enquanto dramáticas, foram compostas para serem lidas - os closet drama, comum no século XIX inglês (como algumas peças de Percy Bysshe Shelley ou Lord Byron) -, ainda carregam os traços composicionais básicos de uma peça (com fala de personagens, didascálias, etc).
}

Texto Digital, Florianópolis, Santa Catarina, Brasil, v. 12, n. 2, p. 35-58, jul./dez. 2016. ISSNe: 1807-9288. 
palco, clima, tons de vozes, etc. e ao qual o público não terá acesso textual durante a execução, 2) e um "texto principal" que consiste na fala efetiva dos personagens que será executada discursivamente na execução ${ }^{7}$. Há, então, uma distinção entre o momento em que a peça é lida - em que o "público" leitor tem acesso à leitura da didascália e esta projeta/constitui o estado das coisas para a fala/discurso do texto principal - e o momento em que a peça é executada - cujas indeterminações são determinadas e cujas objetividades apresentadas são efetivadas materialmente pela montagem cênica em objetividades reais ${ }^{8}$, atualizando uma série de potencialidades em palco.

Partindo da divisão ontológica da obra de arte literária e com as direções de palco em mente, Ingarden estabelece quatro momentos da peça teatral, tendo a encenação como um momento entre a peça escrita e a execução completa, sendo a encenação uma atualização de certos elementos do texto secundário, mas não a execução total ${ }^{9}$. Temos, então:

1) a obra escrita - o autor compõe o texto principal $A$ e o texto (indicações) B como objetividades indeterminadas, potencialmente determináveis;

2) a encenação - em que os atores, diretor, ajudantes, colocam em cena - atualizam - certos elementos potenciais do texto B (certos elementos, que seriam formulados pelo estado das coisas, são concretamente determinados) e, assim, também atualizam alguns do texto A;

\footnotetext{
${ }^{7}$ Com base em seu corpus literário, Ingarden afirma que romances e poemas são distintos do drama. Não pretendo aqui subscrever essa afirmação completamente, já que há romances e poemas que portam os elementos que Ingarden identifica como característicos de peças teatrais (como alguns contos de Ernest Hemingway quase completamente em diálogos, ou os poemas dramáticos de Fernando Pessoa). Meu intuito aqui é justamente mostrar a proximidade do funcionamento de peças teatrais com a dos exemplares deste artigo. Inversamente, é interessante ressaltar, como explora Theresia Birkenhauer (2012), que o teatro contemporâneo - pósdramático - facilmente assimila e adapta ao seu espaço, obras que não foram compostas para serem executadas.

8 Dentro de uma noção de "algo estar por outro", esses objetos reais ainda podem representar outra coisa, como, por exemplo, um pau por uma espada.

9 O conceito utilizado por Ingarden é Schauspiel, literalmente jogar na cena, encenar ou representar, sendo o ator chamado de Schauspieler. Em uma leitura diferente, Eli Rozik (2006) sugere que a noção poderia ser entendida como a "produção" da peça teatral, mas está parece retirar um pouco da noção acional sugerida por Ingarden em sua escolha conceitual.
} 
3) a execução - ato performático em que os atores atualizam as potencialidades do texto A (da mesma forma que toda atualização é distinta, toda performance efetiva também será, até mesmo aquela executada pela mesma companhia, no mesmo teatro, etc.);

4) concretização - o público e atualiza mais ainda o texto $A$, a partir da recepção/apreensão dos eventos ${ }^{10}$ (INGARDEN, 1973, MITSCHELING, 1999).

Ingarden traça, desta forma, uma progressiva concretização da peça escrita até uma atualização de objetividades reais na performance cênica e apreensão do público, lembrando que há sempre um grau de indeterminação restante dentro do espectro de possibilidades que permanece ao longo de toda concretização. Uma atualização "total" ou "perfeita", mesmo no drama, é impossível.

A divisão, que pode aparentar estranha entre encenação e a execução, talvez possa ser clarificada através das obras digitais Liberdade (2014) (Fig. 02) ou o Palavrador (2006) (Fig. 01).

$10 \mathrm{O}$ que acontece no palco é real, mas ainda é possível lançar mão de elementos que necessitem de uma concretização por parte do espectador. Um exemplo seria o ator que usa um pedaço de pau como "espada". O que existe como objeto real é um pau. É a ação do espectador, perante a indicação cênica de que aquele objeto real deve ser reconhecido como outro, que intencionalmente o concretiza como "espada" (INGARDEN, 1973). 
Fig. 01 Ambiente do Palavrador

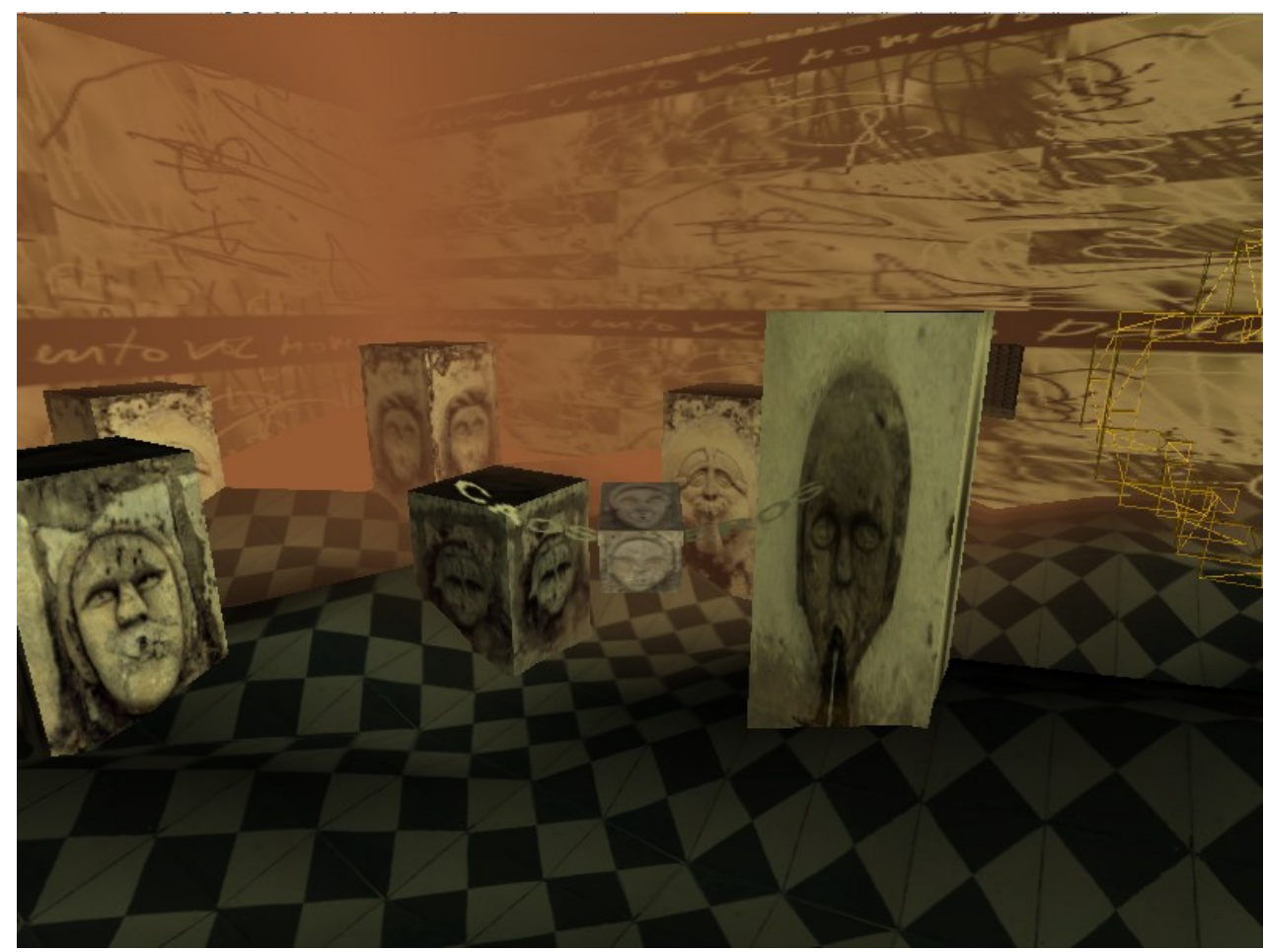

Ambas as obras são ambientes tridimensionais interativos a serem jogadas/utilizadas em computadores pessoais que confluem sons, textos, imagens, vídeos, objetos tridimensionais, acidentes geográficos e seres digitais (pássaros e sapos de origami ou boids voadores compostos de palavras). $\mathrm{O}$ usuário pode navegar livremente por esses ambientes interagindo com diversos elementos ao seu redor ${ }^{11}$. Ambas as obras são, comumente, indicadas como literatura digital ou poesia digital.

${ }^{11}$ Tendo em vista o foco teórico do presente texto, me atenho a meramente indicar as duas obras, ambas gratuitamente disponíveis online, para a navegação do leitor e já abordadas em outros artigos meus: O Palavrador e a relação humano-máquina a partir do conceito de hábito merleaupontiano (2015) e Invasões e permanências conceituais na arte digital (2014).

Texto Digital, Florianópolis, Santa Catarina, Brasil, v. 12, n. 2, p. 35-58, jul./dez. 2016. ISSNe: 1807-9288. 
Fig. 02. Ambiente do Liberdade.

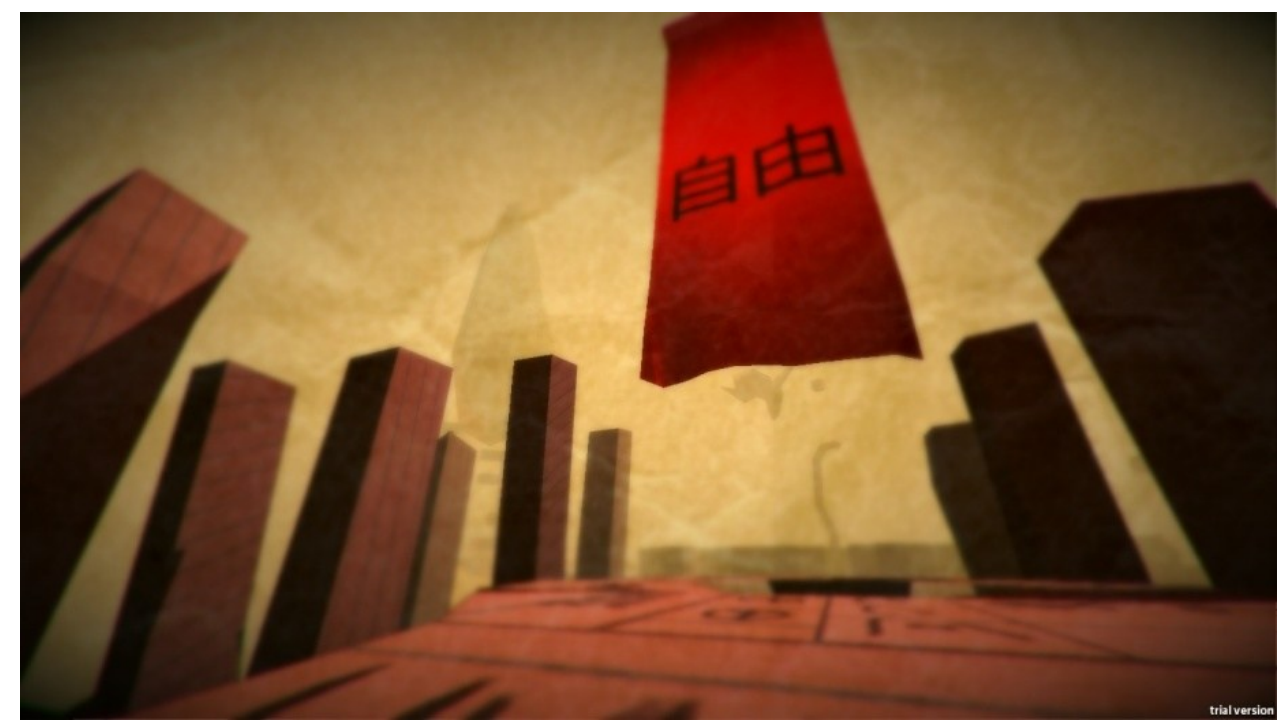

Se voltarmos aos momentos propostos por Ingarden para a peça teatral, é psíveosl esboçar um paralelo para a obra de arte digital:

1) programa como regra ou código-fonte base para existência dos outros momentos, instruções para a operação por/num computador (configuração potencial para uma atualização possível em uma máquina);

2) programa em funcionamento em um computador específico, atualizando uma série de elementos ambientais do código-fonte pela máquina (no caso específico do Palavrador ou Liberdade seria o ambiente efetivamente renderizado na tela, "rodando" pronto para uso $\left.^{12}\right)$;

\footnotetext{
12 Renderizar, do inglês render, significa transmitir, considerar ou passar algo. Aqui, está para o termo de uso em programas de edição de imagem, vídeo ou áudio digital em que renderizar é o processo de gerar algo (uma versão fixa utilizável) depois de ter editado ou construído a versão inicial ainda alterável. É a produção de algo. No caso do jogo, renderizado é ele efetivamente na tela funcionando jogável.
}

Texto Digital, Florianópolis, Santa Catarina, Brasil, v. 12, n. 2, p. 35-58, jul./dez. 2016. ISSNe: 1807-9288. 
3) programa sendo utilizado pelo usuário, atualizando os elementos potenciais restantes da obra já renderizados no computador (o usuário navegando no ambiente do Palavrador ou Liberdade, efetivando movimentos, levando textos, imagens e sons a entrarem em ação e interação);

4) concretização, a apreensão do usuário do que acontece em evento, atualizando elementos que agora existem pela sua interação e ação no mundo ${ }^{13}$.

Podemos, com efeito, traçar certo paralelo entre as bases iniciais em ambos os tipos de obra de arte. Isto é, entre o código-fonte da arte digital e a obra escrita da peça teatral. Ambos equivalem à obra de arte como configuração esquemática na divisão da obra de arte literária. A partir desse ponto inicial, podemos compreender uma progressiva concretização e atualização da obra de arte teatral e digital pela performance, em que ambas estão inicialmente pautadas em um código, que indica e permite diversas e distintas ações performáticas para concretização.

\section{Hierarquia ontológica}

A concatenação de atualização de potencialidades expõe, segundo Ingarden (1973), uma distinção entre a obra de arte "puramente" literária e peça teatral (como uma obra de arte literária dramática). Isso porque a obra de arte literária está hierarquicamente dividida entre os momentos - obra de arte (como configuração esquemática) e (ato de) concretização (que pode resultar em um objeto estético ${ }^{14}$ ), através da leitura ou declamação - enquanto que a obra de arte

\footnotetext{
${ }^{13}$ Aqui também há a concretização do que há em tela (como o exemplo do "pau por espada" acima). Na obra Liberdade, por exemplo, existe um local em que o leitor encontra duas cabeças e áudios de uma série de conversas entre casais, que estão comendo. É o leitor que, ao ouvir, mexer e guardar memórias, reconhece aquele ponto de sons e imagens como "restaurante".

${ }^{14}$ É importante ter em mente que para Ingarden a obra de arte não está intrinsicamente ligada à estética como na tradição subjetivista de Kant e Schiller. Para Ingarden (1973) a obra de arte é uma construção/configuração (Gebilde) estratificada esquemática. O que significa que ela é uma formação de esquemas potencial - held in readiness (Parathaltung) -, que deve ser efetivada, i.e., concretizada pelos atos de um leitor. A estética compreende uma faceta epistemológica, portanto, posterior e tributária à ontologia da obra de arte. Ela está ligada à subjetividade do receptor. Para
}

Texto Digital, Florianópolis, Santa Catarina, Brasil, v. 12, n. 2, p. 35-58, jul./dez. 2016. ISSNe: 1807-9288. 
teatral se atualiza em quatro momentos e se perfaz no ato performático. Portanto, há, no teatral, uma maior complexidade ontológica por haver mais momentos em comparação à obra "puramente" literária, e pelo fato de a peça teatral se atualizar em conjunto com outros agentes (sobretudo, na concretização dos elementos dos textos secundários). É essa proximidade e, ao mesmo tempo, diferença, que leva Ingarden a falar do teatral como "caso limite".

Na obra teatral, como na obra "puramente" literária, a complexidade está marcada por uma hierarquia ontológica em que um momento é ontologicamente dependente do outro para sua existência ${ }^{15}$. Não há autonomia das partes, pois cada uma está ontologicamente fundada na anterior e, ao mesmo tempo, cada momento produz seu sentido por referência ao momento posterior. A obra escrita faz sentido em relação à encenação, e esta em relação à sua execução e apreensão (FERREIRA, 2010; MITSCHERLING, 1999) ${ }^{16}$. Da mesma forma, no digital, o programa em código só faz sentido (de modo acional) com relação ao seu funcionamento em uma máquina e posterior utilização por um usuário. É o ato de execução que une e atravessa essa hierarquia e confere à obra de arte uma identidade ou sentido. Assim, novamente, vale ser dito que a obra de arte se perfaz no ato.

Essa hierarquia ontológica da peça teatral serve para compreender as obras digitais, no sentido de que 1) ambas - teatro e digital - têm uma atualização

\footnotetext{
Ingarden, esta subjetividade não é o que funda o modo de ser da obra de arte. Assim, afirmar a estética antes da ontologia implicaria cair no mesmo erro de que Ingarden acusa Husserl em seu On the motives which led Husserl to transcendental idealism (1975b), isto é, de colocar a epistemologia antes da ontologia. Para uma análise mais aprofundada da distinção entre obra de arte e estética, veja a tese Ação e artifício: por um conceito de arte e ontologia da obra de arte a partir da produção letrada seiscentista, da poesia experimental e da arte digital contemporânea (TAVARES, 2015).

${ }^{15}$ Não se deve confundir aqui hierarquia ontológica com qualquer grau de valoração, trata-se meramente de uma questão de modo de ser e operar das obras em questão.

${ }^{16}$ Talvez seja interessante pensar essa relação ontológica diante de costumes do teatro contemporâneo - pós-dramático - de levar à execução obras literárias não compostas para tal (executando qualquer texto de qualquer gênero). Tal costume indicaria que é possível estabelecer uma mudança dessa hierarquia ontológica com relação ao uso pragmático (relacional e situacional) da obra de arte literária. Isto é, é possível transpor, com algum trabalho, um texto nãoteatral - como a Obscena Senhora D de Hilda Hilst (2011) - para uma execução, o que acarreta uma alteração de sua hierarquia ontológica e indicaria que o sistema de hierarquia ontológica não é absolutamente inerente ao texto, mas ao seu uso intencional pragmático.
}

Texto Digital, Florianópolis, Santa Catarina, Brasil, v. 12, n. 2, p. 35-58, jul./dez. 2016. ISSNe: 1807-9288. 


\section{em múltiplos estágios, em que a concretização de elementos distintos é} executada por diferentes agentes (esses diferentes agentes são atores, computadores e outros usuários, heterogêneos à obra de arte, mas necessários para sua concretização) e 2) a atualização do estado de coisas se dá tanto em objetividades intencionais (um pedaço de pau no palco sendo intencionado como uma espada pelo público e atores), quanto em realidades efetivas. Aquilo que em uma leitura teria que ser concretizado intencionalmente - estados de coisas, objetividades apresentadas e aspectos esquemáticos -, em uma apresentação teatral ou num poema digital passa a existir efetivamente como realidade. É necessário lembrar que, como já foi dito, basta a declamação (leitura em voz alta) de um poema ou de um sermão para estarmos operando com concretizações da obra de arte em objetos reais e não só intencionais ${ }^{17}$. O que não implica, de forma alguma, na dispensa do intencional, já que, como propõe Ingarden em seu artigo "Phenomenological aesthetics: an attempt at defining its range" (1975a), existe um grau de intencionalidade para que um objeto real mármore esculpido - seja reconhecido como obra de arte - a Vênus de Milo ${ }^{18}$.

Logo, há concretizações reais e materiais efetivadas em mais etapas e por uma diversidade de entidades agentes que não somente o receptor. São agentes que concretizam elementos fora do controle específico do leitor/público/usuário. No caso do teatro, há atores, diretores, coreógrafos, e público humanos ${ }^{19}$, enquanto que nas obras digitais há vários elementos atualizados por máquinas, computadores e por outros usuários em rede (em obras como Liberdade, que constituem ambientes de interação coletiva ao modo dos $\mathrm{MMOs}^{20}$ ). Chamo todos estes elementos de agentes - inclusive as máquinas e computadores - no sentido de que atualizam algo de forma distinta, a partir de uma série de possibilidades.

\footnotetext{
17 Trata-se de uma escolha de como se concretizar uma obra de arte literária.

18 Noção esta que irá atravessar grande parte das formulações contemporâneas da filosófica da arte anglófona, como Danto (1981) ou Carroll (2003).

19 É importante lembrar-se da interação do público - em teatro de rua, obras experimentais etc. -, em maior ou menor grau, não só como um espectador passivo (da ideia de "quarta parede"), mas como mais um elemento que interfere e altera fisicamente a concretização das obras, como elementos necessários para a obra de arte teatral (com a interação servindo mesmo como mais elementos para a peça).

${ }^{20}$ Sigla em inglês para "massively multiplayer online game", traduzido como "jogo multijogador massivo online".
}

Texto Digital, Florianópolis, Santa Catarina, Brasil, v. 12, n. 2, p. 35-58, jul./dez. 2016. ISSNe: 1807-9288. 
Isto é, os elementos por eles concretizados não são o resultado de uma predeterminação simples, mas a atualização entre uma gama de possibilidades distintas, por vezes aleatória. Tal é o caso do Palavrador, em que a máquina efetiva objetos e seres "viventes" - boids - via algoritmos no ambiente ${ }^{21}$.

\section{Identidade na multiplicidade}

O que vemos, então, é que uma obra de arte literária ou peça teatral, apesar de seus vários momentos heterogêneos - i.e., ontologicamente distintos -, ainda possui uma identidade (unidade), já que identificamos, por exemplo, The Tragedy of Hamlet, Prince of Denmark tanto o texto impresso desta quanto sua execução. Com isso em mente, o questionamento acerca da identidade da obra de arte teatral diante da pluralidade de momentos de uma hierarquia ontológica também pode ser utilizada para compreendermos a identidade perante as múltiplas e diferentes concretizações reais (e materiais) que existem nas obras de arte digitais, pois são obras que, em suas concretizações reais (e não meramente intencionais), constantemente marcam a diferença com relação às distintas concretizações. Há diversas formas de concretizar The Tragedy of Hamlet ou o personagem Hamlet (até, talvez, o limite extremo de um Die Hamletmaschine). Há vários caminhos possíveis de navegar, vários percursos e rumos a trilhar o Palavrador e Liberdade, e todos marcam sua diferença atual/real material de concretização (e não somente interpretativa). São obras que portam infinitas possibilidades materiais e nunca podem ser completamente exauridas. Entretanto, por se assemelharem ao nosso hábito mundano de posicionamento espaçotemporal - para usar uma noção de Merleau-Ponty (2006) -, eles tendem a, ambiguamente, ao mesmo tempo em que marcam a diferença constante das concretizações, dar uma impressão de "já trilhados" ou "já explorados" por completo. Quando, por exemplo, passo mais de uma vez pelo tubo central do Palavrador e escuto o começo dos poemas de Alckmar Santos e Álvaro Andrade Garcia, sozinhos ou entrelaçados, tendo a achar que já passei por ali, já ouvi os poemas, da mesma forma que tendo a achar que conheço minha cozinha e já

${ }^{21}$ A tentativa aqui não é a de postular, precisamente, que a agência maquínica seja equivalente à agência humana, mas sim de ilustrar que há um tipo de agência.

Texto Digital, Florianópolis, Santa Catarina, Brasil, v. 12, n. 2, p. 35-58, jul./dez. 2016. ISSNe: 1807-9288. 
trilhei por ela de todos os modos possíveis. O que é, obviamente, uma ilusão dada por uma construção de identidade, por habitar aquele local. Nunca é possível estar duas vezes exatamente no mesmo lugar, da mesma forma, nas mesmas condições espaçotemporais. Há sempre uma diferença. Se de repente escorregamos e caímos, nos damos conta de que vemos o ambiente habitual de outro modo, por outro ângulo, i.e., quebramos um hábito e somos lançados a uma experiência nova.

Mas a pergunta é: como chegamos a uma identidade através da pluralidade de concretizações materiais? Para a formulação da resposta, Ingarden (1973) se apoia na concepção fenomenológica da construção de uma totalidade por uma diversidade de aspectos, em que intencionamos uma identidade com base na multiplicidade. Na fenomenologia: "A consciência é "de" algo no sentido que intenciona a identidade dos objetos, não só o fluxo de aparências que são apresentadas a ela" (SOKOLOWSKI, 1999, p. 20)22. A partir disso, devemos notar que existe uma diferença entre a identidade e as múltiplas aparências que apreendemos: "A identidade que é dada através de sua multiplicidade de aparências pertence a dimensão diferente daquela da multiplicidade." (SOKOLOWSKI, 1999, p. 30) ${ }^{23}$. Isso significa que a identidade da peça é algo distinto da multiplicidade de apreensões da peça. A identidade é uma construção intencional a partir da diversidade de facetas pela qual experienciamos a peça. Se em um cubo eu atribuo unidade/identidade, a despeito de nossa vontade, mesmo quando sempre apenas vejo faces e aspectos distintos em posições e tempos distintos, na peça teatral atribuo/construo identidade a partir da pluralidade ontológica de momentos da peça. O que quer dizer que a identidade está fundada sobre a coisa e não são meras subjetividades. Desta forma, não há uma "única coisa", mas uma pluralidade que Ingarden pretende sempre ontologicamente marcar como tal em sua plena heterogeneidade. O que também significa, conforme foi abordado acerca da obra de arte literária e como coloca Debora Pazetto Ferreira:

22 "Consciousness is 'of' something in the sense that it intends the identity of objects, not just the flow of appearances that are presented to it" (SOKOLOWSKI, 1999, p. 20).

23 "The identity that is given through its manifold of appearances belongs to a dimension different from that of the manifold" (SOKOLOWSKI, 1999, p. 30).

Texto Digital, Florianópolis, Santa Catarina, Brasil, v. 12, n. 2, p. 35-58, jul./dez. 2016. ISSNe: 1807-9288. 
A obra não se identifica com nenhum dos níveis mencionados por Ingarden, tampouco com a soma de todos. Ela é o traço que sublinha todos os seus momentos, que os amarra e justifica sua interdependência (FERREIRA, 2010, p. 60).

De certa maneira, poder-se-ia, então, dizer que esse traço pode ser colocado como a ação de execução performática (intencional para Ingarden), que constrói a ligação dos momentos.

Com efeito, as obras Palavrador e Liberdade não podem ser localizadas exclusivamente no seu código-fonte, no programa operando sozinho em um computador, nem somente na sua execução pelo usuário ou na recepção deste (muito menos em estados psíquicos deste). O que Ingarden faz é identificar esse traço que sublinha a possibilidade de ligação entre os momentos em dois estratos que, justamente, não têm sua realização plena na peça teatral, i.e., o estrato de unidades de significação e o estrato de objetividades apresentadas:

É precisamente a identidade dos estratos não realizáveis de unidades de significação e objetividades apresentadas que, de fato, permitem realizar uma coordenação entre estas duas obras heterogêneas, e nos permitem falar neste sentido, mas somente neste sentido, de "um e o mesmo" drama em duas formas diferentes, da encenação e da obra de arte puramente literária (INGARDEN, 1973, p. 322, itálicos do autor) ${ }^{24}$.

A razão disso é que quando esses estratos são concretizados pela leitura, eles intencionam os estados das coisas que são materialmente concretizados no caso da execução teatral. E é por causa disto que se torna possível ligar o texto escrito e a performance efetiva através de uma comparação entre eles. De certa forma, isto é fundamentar a possibilidade de constituir uma identidade na multiplicidade através do elemento textual (a obra de arte como configuração esquemática). Deve ficar claro, aqui, que não se trata de uma ligação intrínseca ou essencial (como se uma coisa estivesse preexistente na outra), mas da possibilidade de atribuirmos uma relação e falarmos "da mesma peça", sem esquecermos que

\footnotetext{
${ }^{24}$ It is precisely the identity of the non-realizable strata of the meaning units and the represented objectivities that in fact allows a coordination between these two heterogeneous works to be established and allows us to speak in this sense, but only in this sense, of "one and the same" drama in two different forms, that of the stage play and that of the purely literary work (INGARDEN, 1973, p. 322).
} 
peça escrita, encenação e execução são entidades ontologicamente heterogêneas. E deve-se ter claro que Ingarden (1973) não prega nenhum tipo de grau de "fidelidade" ao texto "original". Este só pode existir por imposições externas à obra de arte, a serem estipuladas, com certo grau de arbitrariedade, pelo ambiente ou cenário artístico em questão.

Dessa maneira, chegamos à concepção de que a identidade pertence a uma estrutura intencional. Nesse sentido, quando Ingarden (1973) estabelece o traço de união sobre os dois estratos, ele está concebendo a intencionalidade como base para um artefato abstrato, noção de Thomasson (1999), e, logo, para a obra de arte $^{25}$. Ingarden funda a possibilidade de um traço delineador sobre o elemento textual, mas mantém a diferença entre eles e indica que, "somente" nesse sentido, é possível falar de "um mesmo", ou seja, não há uma igualdade ontológica entre os elementos ${ }^{26}$. Destarte é possível aprender, com a análise de Ingarden sobre o teatro, que há a possibilidade de identidade para uma multiplicidade sem anular a pluralidade ontológica das partes, valendo tanto para as várias etapas da hierarquia ontológica, quanto para as múltiplas concretizações reais possíveis no teatro e no digital.

Assim, apesar do infinito espectro de possibilidades de atualizações reais e distintas - dos caminhos que são trilhados e vistos, frases que são formadas, interações acionados ou diálogos ouvidos - fica evidente a possibilidade de um traço de união dentro da multiplicidade, de forma que em momento algum duvidamos que utilizamos a mesma obra, que percorremos a mesma Liberdade.

25 O conceito de artefato abstrato, proposto por Amie Thomasson $(1999,2004)$ a partir de sua leitura da obra de Ingarden, indica entidades similares a artefatos físicos construídos - visto que podem ser feitos e igualmente destruídos -, que necessitam de alguma base real/material espaçotemporalmente localizada e determinada de entidades contingentes - como livros, textos, pessoas -, mas que são abstratos pelo fato de não terem localização espaçotemporal precisa, podendo então comportar múltiplas instanciações. São coisas como leis, instituições, conceitos, personagens e uma série de entidades culturais elaboradas através de atos intencionais. Em termos mais específicos, artefatos abstratos não têm independência ontológica. Eles vêm a ser a partir da intencionalidade humana e dependem sempre de alguma forma de performance para existir.

${ }^{26}$ Esse elemento pode servir de baliza entre o que ainda é a obra, porém, a delimitação exata está além da questão de identidade (e concerne a tradições e escolas de interpretação). Novamente, o elemento de valor não está em questão, mas o de identidade, lembrando que uma execução considerada boa também pode ser a mais "infiel", da mesma forma que uma execução "fiel" pode ser considerada de má qualidade.

Texto Digital, Florianópolis, Santa Catarina, Brasil, v. 12, n. 2, p. 35-58, jul./dez. 2016. ISSNe: 1807-9288. 
Isso significa que a "localização" da identidade das obras estaria fundada sobre o artefato e a ação a ser executado, i.e., se funda sobre o artefato abstrato.

O teatro permite salientar três pontos úteis para compreender a arte digital: 1) a hierarquia ontológica; 2) a concretização por outros agentes ou em conjunto, e 3) a concretização em fatos reais e intencionais. Estes, por sua vez, permitem abordar duas questões com que estamos a lidar: 1) a identidade diante de uma obra com momentos distintos, e 2) a identidade diante dos vários resultados reais (não só interpretativos) possíveis desta, cuja distinção, em vários momentos, permite compreender a construção de uma identidade perante as concretizações possíveis. E, ainda, ambos podem ser compreendidos através da noção de artefato e ação. Quando Ingarden funda a possibilidade de baliza e relação entre o texto escrito, encenação e a execução efetiva, é como dizer que as instruções para ação - configuração esquemática - fundam a possibilidade de identidade.

\section{Linguagem e ação}

Entretanto, essa hierarquia fundada em um elemento linguístico textual como configuração esquemática - a peça escrita no teatro, código no digital -, de forma alguma deve ser entendida como uma linguisticidade da ação ou um sentido linguístico semântico enquanto necessidade ou finalidade para obra de arte. Ela representa sim, nos casos analisados, uma base artefactual textual que possibilita e dá as margens para construção/atualização. $O$ textual está como base para o início, e não como ponto de chegada. O ponto de chegada no digital, como no teatro, pode ser um agir sem fala ou texto.

O que ocorre, entre a obra de arte teatral com relação à obra de arte literária, é que a peça executada tira o peso e confere um papel auxiliar ao estado das coisas intencionalmente projetadas. $O$ modo de operar da peça teatral impede $O$ funcionamento de certas partes do estrato de unidades de significação e objetividades apresentadas, fora a sua existência como fala dos personagens, já que os elementos normalmente dados por esta (no texto secundário) são 
efetivamente colocados em cena por objetos no palco e ações reais dos atores. Até mesmo elementos psíquicos ou emocionais, que eram sugeridos por construções textuais na obra de arte literária - por ritmos, escolhas lexicais, pontuação, etc. -, são, na performance, efetivamente apresentados no palco pela pessoa, voz e força dos atores. $E$ isso vale da mesma forma para as obras digitais. No Palavrador e Liberdade, temos um ambiente concreto, real, em que ouvimos vozes - com tom, intensidade, pausas, acentos - lendo os poemas, vemos os vídeos e ouvimos o canto com toda sua carga performativa. Ou seja, apesar de a peça executada ou de o poema digital ainda estarem fundados na textualidade do estrato fônico, da significação no discurso dos atores ou do código (todos com algum grau semântico) e suas atualizações formais como segundo momento da hierarquia, o ato performático de concretização substitui um resultado semântico ou projeção de estado de coisas por um resultado que é ação real. Embora todas essas obras sejam fundadas no textual, elas têm resultados que são atos. Esse fator tira o peso semântico da concretização ao colocá-lo sobre o acional. A concretização pelo ato faz com que o final da obra de arte não seja necessariamente semântico, mas sim ato (ato significante, mas ato). A obra de arte teatral e digital, como obras de arte que funcionam por meio de concretizações reais acionais (i.e., como um objeto esquemático linguístico textual que leva à ação) também estabelece a possibilidade de um sentido nãosemântico. Na obra de arte cênica e digital a linguagem não necessariamente "comunica" como "dizer" semântico. Sua significação pode se dar por outras maneiras. Os múltiplos caminhos do Palavrador e Liberdade - a ação de perambular ou voar por esses múltiplos caminhos - são uma relação e não só um significado ou representação linguística de alguma coisa. São um movimento e um modo de se portar/agir. Desta forma, não há como abarcá-lo no semântico representacional.

Logo, a pergunta que surge é: qual o lugar da instrução ou prescrição (texto secundário) na obra de arte? 


\section{Instruções para ação}

Se acompanharmos o que acontece com o teatro, veremos que existem obras que são somente texto secundário, somente instruções para ação. É o caso de várias peças tardias de Samuel Beckett (2010), feitas para televisão como Quad (Fig. 03 e 04) e Nacht und Träume, em que não há palavras em palco, mas uma configuração e esquematização de atos, cores, sons para a construção de algo, de uma ação esquemática, uma performance (no caso de Quad, todos como constantes reiterações e permutações de possibilidades $)^{27}$.

Fig 03: Quad // de Beckett 28 .

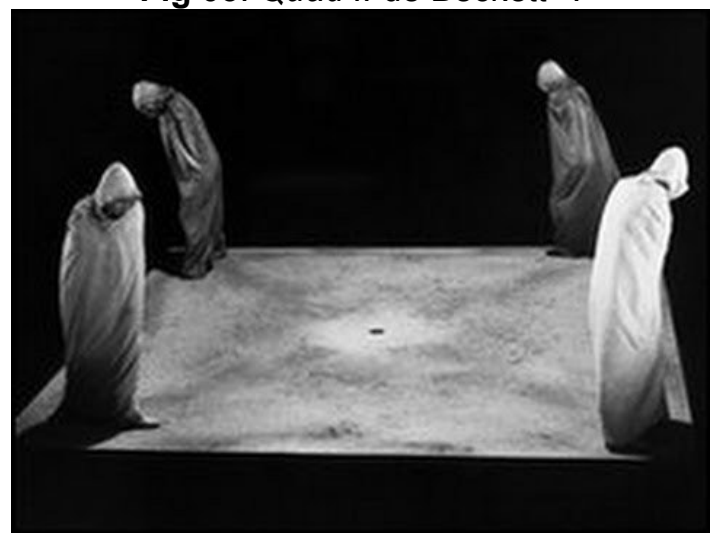

Fig 04: excerto do esquema de movimentação dos atores de Quad.

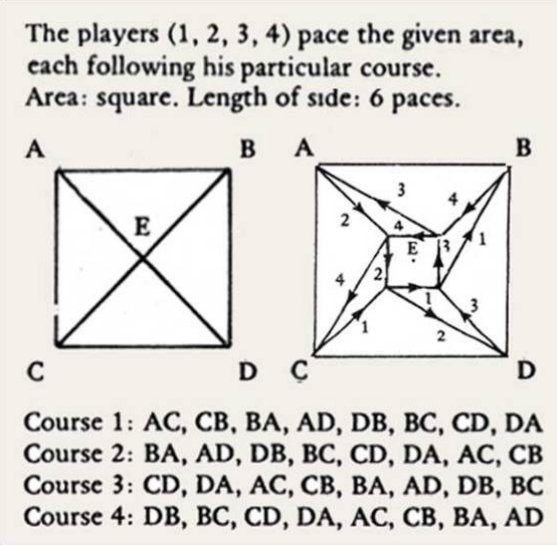

${ }^{27}$ Mesmo nas peças que não são compostas para televisão, há, nas obras tardias de Beckett, uma crescente importância conferida ao texto secundário, como indicação de gestos, posições e movimentos no palco.

${ }^{28}$ Na primeira transmissão na Alemanha, por Süddeutscher Rundfunk, em 8 de outubro de 1981, dirigido por Beckett (2010).

Texto Digital, Florianópolis, Santa Catarina, Brasil, v. 12, n. 2, p. 35-58, jul./dez. 2016. ISSNe: 1807-9288. 
Há algo similar nas obras de arte digitais, pois, mesmo não havendo um texto no monitor para ser lido ou ouvido quando usamos a obra (sendo, digamos, a obra só imagens e movimentos), há um código-fonte que fundamenta esta como um programa, que dita o que pode ou não potencialmente acontecer (e o que nós podemos fazer), dita as regras para esse mundo-programa. E se cavarmos mais a fundo, há a instrução em linguagem maquínica (normalmente ilegível para um humano por ser um código numérico bastante extenso) que, em primeiro nível, ditam as regras para a execução da obra na máquina. Ou seja, esse modo de operar do digital, próximo ao do teatro, indica que a linguagem na arte digital tem um papel primário fundamental, mas quando a obra está "em cena" essa figura muda ${ }^{29}$. Resumidamente, há dois momentos diferentes de linguagem na peça teatral e obra digital: 1) a linguagem-código fundante, a partir da qual a obra vem a ser e existe (no momento 01 do código-fonte), e 2) a linguagem como mais um elemento na obra enquanto esta acontece (a partir do momento 02 do esquema acima). Se ela é fundante no primeiro momento (ela cria um mundo e seu modo de operar), no segundo, ela pode ser apenas mais um elemento entre imagens, sons, movimentos, etc. Fato que pode ser notado no Palavrador e, em menor grau, em Liberdade, pois, apesar da sua importância em jogo, a linguagem subsiste no mesmo nível com outros elementos de som e imagem dentro de um ambiente para a ação do usuário (e sua concretização pela ação no jogo). $E$ ainda, o que há de texto no Palavrador e em Liberdade tende a adquirir força como fala, ou seja, é executado pela máquina como som para ser ouvido e não lido como grafema. Assim, a predominância textual como código/fundamento para ação (para a atualização) não implica em sua importância ou necessidade na obra rodando (na execução ou no programa sendo usado pelo usuário). O ambiente digital vem a ser/existir por causa de um código, mas, a partir daí, aquilo que o concretiza é a ação.

A pergunta que pode se colocar é: isso ainda é uma obra literária? Ou, qual o limite do literário? Alguns poderiam dizer que uma obra que não dá grafemas ou fonemas ao leitor não seria literatura. Contudo, o que dizer de um tipo de obra

${ }^{29}$ Aqui estou pensando uma noção de linguagem bastante ampla, mas ainda pautada pela reiterabilidade e permutação de elementos para seu funcionamento.

Texto Digital, Florianópolis, Santa Catarina, Brasil, v. 12, n. 2, p. 35-58, jul./dez. 2016. ISSNe: 1807-9288. 
que se dá a entender pelo mesmo sistema ontológico do literário? Ou, pelo menos, por um modo de operar tão similar? Ingarden, ao chamar as peças teatrais de "caso limite" da obra de arte literária, está justamente notando essa posição ambígua ou eternamente provisória desta com relação aos artefatos literários. Talvez o caso seja de afirmarmos que sim, tanto o teatral quanto 0 digital sejam literatura, mas que, ao mesmo tempo, literatura seja algo diferente que não se encerra no limite do semântico. Destarte, o modelo ontológico base para a compreensão do teatral em Ingarden é elaborado a partir do literário. Entretanto, este segundo modelo ontológico (o da peça teatral), quando posto diante das produções digitais, permite-nos rever o conceito de literatura, expandindo-o também para o acional.

\section{Para um conceito de obra de arte literária digital}

Diante dessa multiplicidade de instruções, podemos dizer, a partir das formulações de Ingarden, que a obra de arte é um artefato, uma instrução para concretizar, um artefato para ação, para um agir operatório. A diferença marcante na obra de arte digital é que, nesta, o texto B é efetivado/atualizado por uma máquina. Inversamente, podemos inferir que a instrução para ação do teatro pode ser pensada como uma maquinização do humano, ou melhor, uma artificialização da ação humana segundo um conjunto de instruções, mas que de forma alguma deve ser encarada como negativa, e sim deve ser entendida do mesmo modo que o epíteto unxavń (mēkhanế) de Ulysses na Odisséia, i.e. engenhoso, artífice, hábil, astuto, aquele que constrói os artifícios e constantemente altera a si mesmo, aquele que cria "regras" para si mesmo, para artificializar a própria ação. Portanto, indica que ser arte é ser artifício, é ser ato de (se) artificializar. Arte é agir e artifício.

Assim, apesar de algumas vezes pesar contra Ingarden uma crítica de que ele apenas trata de obras "clássicas" ou de que sua filosofia foi inteiramente pensada para tratar dessas obras tradicionais e, por isso, não daria conta da arte contemporânea. O que vimos aqui é que seu sistema foi construído de tal maneira - analisando metodologicamente o modo de ser da obra de arte por um viés 
ontológico formal realista - que, apesar de ter sido pensado tendo como exemplares obras de arte como Ibsen, Conrad, Dante, Goethe, Shakespeare, Faulkner, a Vênus de Milo, Van Gogh, entre outros, ela permite pensar e compreender bem as produções artísticas contemporâneas digitais em sua plenitude, dando-nos não um modelo pronto, mas uma ferramenta conceitual a partir do qual pensar distintas formas artísticas. Ingarden, portanto, criou um sistema abrangente e que pode abarcar obras de arte para além de seu tempo, demonstrando efetivamente a elaboração de um conceito formal de obra de arte que não nos prende a um conjunto de obras de forma normativa, mas que nos indica as possibilidades e caminhos para compreender e elaborar o que pode vira-ser.

\section{FROM THE THEATRE TO THE DIGITAL: AN ONTOLOGY FROM ROMAN INGARDEN}

ABSTRACT: In this essay, I affirm that it is possible to utilize Roman Ingarden's work on the stage play/theatre to trace the basis for an ontology of the digital work of art, based on the convergence between both types of productions' mode of being. This convergence can be found in: a) the fact that both are works which encompass a material concretization; b) the stratified complexity and ontological hierarchy capable of bearing diverse levels of concretization by distinct human and nonhuman agents; c) the notion of identity that is given through the multiplicity of concretizations; and d) the role of language which distances itself from a semantic function towards an actional focus in which the textual element characterizes itself as an indication for performative action. Consequently, based on these parallels, it is possible to question the concept of literature applied to digital works (as digital literature or digital poetry), being that the digital work of art, by its mode of being, would be ontologically closer to the stage play or dramatic work of art. Thus, it is possible not only to revise and revisit Ingarden's philosophy, demonstrating its relevance as a theoretical tool for the analysis of contemporary works of art, but also to mark the central position of artifactuality and performativity in digital works of art.

KEYWORDS: Digital literature. Theatre. Ontology. Agency. Roman Ingarden.

\section{Referências}

BECKETT, Samuel. The Collected Shorter Plays. New York: Grove Press, 2010.

BIRKENHAUER, Theresia. Entre fala e língua, drama e texto: reflexões acerca de uma discussão contemporânea. Tradução de Stephan Baumgärtel. Urdimento: revista de estudos em artes cênicas, Florianópolis, n. 18, p. 181-188, mar. 2012. Disponível em: 
<http://www.revistas.udesc.br/index.php/urdimento/article/view/3235/2356>. Acesso em: 28 ago. 2016.

BRAIDA, Celso R. Tópicos em ontologia. Florianópolis: Rocca Brayde, 2013.

CARROLL, Noël. Beyond aesthetics: philosophical essays. New York: Cambridge University, 2003.

DANTO, Arthur. The Transfiguration of the commonplace: a philosophy of art. Cambridge: Harvard University, 1981.

The Philosophical disenfranchisement of art. New York: Columbia University, 1986.

DIPERT, Randall R. Artifacts, art works, and agency. Philadelphia: Temple University, 1993.

. Art, artifacts, and regarded intentions. American Philosophical Quarterly, v. 23, n. 4, p. 401-408, out. 1986. University of Illinois Press / North American Philosophical Publications. Disponível em:

<http://www.jstor.org/stable/20014165>. Acesso em: 28 ago. 2016.

FERREIRA, Debora Pazetto: Análise categorial da arte em Amie Thomasson. 2010. 144f. Dissertação (Mestrado em Filosofia) - Programa de Pós-Graduação em Filosofia, Centro de Filosofia e Ciências Humanas, UFSC, Florianópolis, 2010. Disponível em: <http://www.tede.ufsc.br/teses/PFIL0127-D.pdf>. Acesso em: 28 ago. 2016.

ISEMINGER, Gary. The Work of art as artifact: The British Journal of Aesthetics, v. 13, n. 1, p. 3-16, 1973. Oxford Journals. Disponível em:

<http://bjaesthetics.oxfordjournals.org/content/13/1/3.full.pdf+html> <doi: 10.1093/bjaesthetics/13.1.3>. Acesso em: 28 ago. 2016.

INGARDEN, Roman. The Literary work of art. (trad. George G. Grabowicz) Evanston: Northwestern University, 1973.

. Controversy over the existence of the world. (volume 01). Tradução de Arthur Szylewicz. Frankfurt am Main: Peter Lang International Academic Publishers, 2013.

Phenomenological aesthetics: an attempt at defining its range. The Journal of Aesthetics and Art Criticism, v. 33, n. 3, p. 257-269, primavera. 1975a. Wiley. Disponível em: <http://www.jstor.org/stable/428352>. Acesso em: 28 ago. 2016.

. On the motives which led Husserl to transcendental idealism. Tradução de Arnór Hannibalsson. Den Haag, Netherlands: Martinus Nijhoff, 1975b.

HILST, Hilda. A Obscena senhora D. São Paulo: Globo, 2011. 
KÜNG, Guido. Roman Ingarden (1893-1970): Ontological phenomenology. In: SPIEGELBERG, Herbert. The Phenomenological movement. The Netherlands: Kluwer Academic Publishers, 1994.

LEVINSON, Jerrold. Music, art, and metaphysics: essays in philosophical aesthetics. New York: Oxford University, 2011.

MCFEE, Graham. Artistic Judgement: a framework for philosophical aesthetics. London: Springer, 2011.

MARGOLIS, Joseph: The Ontological peculiarity of works of art. The Journal of Aesthetics and Art Criticism, v. 36, n. 1, p. 45-50, outono. 1977. Blackwell

Publishing / The American Society for Aesthetics. Disponível em:

<http://www.jstor.org/stable/430748>. Acesso em: 28 ago. 2016.

. Recent currents in aesthetics of relevance to contemporary visual artists. Leonardo, v. 12, n. 2, p. 111-119, primavera. 1979. The MIT Press. Disponível em: <http://www.jstor.org/stable/1573833>.Acesso em: 28 ago. 2016.

MARINHO, Francisco; et alii. Palavrador. 2006. Disponível em: $<$ https://docs.google.com/file/d/0B2gzgpil8Ww0N2I4ZmNiMjMtN2RIYy00NGRkLW IzOWEtMzRkNGEzMjEwYzA4/edit?ddrp=1\&pli=1\&hl=en_US>. Acesso em: 27. ago. 2016.

MARINHO, Francisco; SANTOS, Alckmar; et alii. Liberdade. 2014. Disponível em: <http://www.1maginari0.art.br/liberdade/>. Acesso em: 27 ago. 2016.

MERLEAU-PONTY, Maurice: Fenomenologia da percepção. Tradução de Carlos Alberto Ribeiro de Moura. São Paulo: Martins Fontes, 2006.

MITSCHERLING, Jeff. Roman Ingarden's ontology and aesthetics. Quebec: University of Ottowa Press, 1999.

ROZIK, Eli. Ingarden s Notion of 'Stage-Play'. Maske und Khoturn, v. 52, n. 2, p. 715, 2006.

SOKOLOWSKI, Robert. Introduction to phenomenology. New York: Cambridge University, 1999.

TAVARES, Otávio: O Palavrador e a relação humano-máquina a partir do conceito de hábito merleau-pontiano. Polifonia, Cuiabá-MT, UFMT, v. 22, n. 32, pp. 13-36, 2015. Disponível em:

<http://periodicoscientificos.ufmt.br/ojs/index.php/polifonia/article/view/3262/2315> . Acesso em: 26 ago. 2016.

Invasões e permanências conceituais na arte digital. In: VILAROUCA, Cláudia; TAVARES, Otávio; CARVALHO MOURA, Cláudio. (Org.) Criação digital: prática e reflexão. Tubarão: NuPILL/Copiart, 2014. Disponível em: 
<http://nupill.ufsc.br/wp-content/uploads/2014/12/criacao_digital.pdf>. Acesso em: 27 ago. 2016.

. Ação e artifício: por um conceito de arte e ontologia da obra de arte a partir da produção letrada seiscentista, da poesia experimental e da arte digital contemporânea. 2015. 439f. Tese (Doutorado em Literatura) - Programa de PósGraduação em Literatura, Centro de Comunicação e Expressão, UFSC.

Florianópolis, 2015. Disponível em: <http://www.bu.ufsc.br/teses/PLIT0631-T.pdf>. Acesso em: 27 ago. 2016.

THOMASSON, Amie L. Fiction and metaphysics. New York: Cambridge University Press, 1999.

The Ontology of art. In: KIVY, Peter (Ed.). The Blackwell guide to aesthetics. Oxford: Blackwell Publishing, 2004. Disponível em:

<http://www.amiethomasson.org/papers\%20to\%20link/The\%200ntology\%20of\%2 0Art.doc>. Acesso em: 28 ago. 2016.

Roman Ingarden. In: The Stanford encyclopedia of philosophy. Stanford: Metaphysics Research Lab/Center for the Study of Language and Information/Stanford University, 2012. (ed. Edward N. Zalta). Disponível em: $<$ http://plato.stanford.edu/archives/fall2012/entries/ingarden/>. Acesso em: 28 ago. 2016.

Recebido em: 05/09/2016. Aceito em: 23/10/2016. 